Respiration 1994;61(suppl. 1):I-IV

\title{
Contents, Vol. 61, Supplement 1, 1994
}

\section{Contents}

Bellanti, J.A.

Introduction

Bellanti, J.A.; Zeligs, B J.

Current Concepts of Immune Interventions in Children with Respiratory Diseases

Mauël, J.

Stimulation of Immunoprotective Mechanisms by OM-85 BV. A Review of Results from in vivo and in vitro Studies

Collet, J.P.; Burtin, P.; Gillet, J.; Bossard, N.; Ducruet, T.; Dürr, F.; Epicrèche Research Group

Risk of Infectious Diseases in Children Attending Different Types of Day-Care Setting

16

Collet, J.P.; Boissel, J.P.

Aymard, M.; Chomel, J.J.; Allard, J.P.; Thouvenot, D.; Honegger, D.; Floret, D.; Boissel, J.P.;

Collet, J.P.; Dürr, F.; Gillet, J. Bossard, N.; Lyon, L.

OM-85 BV: Primary versus Secondary Prevention

Epidemiology of Viral Infections and Evaluation of the Potential Benefit of OM-85 BV on the Virologic Status of Children Attending Day-Care Centers

20

24

Author Index

32

Subject Index

32 